\title{
Pendidikan Inklusif Bagi Anak Berkebutuhan Khusus Dengan Gangguan Emosi dan Perilaku (Emotional and Behavioral Disorders)
}

\author{
Andreani Elisabeth \\ Program Studi Pendidikan Bahasa Inggris, Universitas Lambung Mangkurat, Banjarmasin \\ e-mail: Andreanie301@gmail.com
}

\begin{abstract}
This study aims to analyze the characteristics of children with special needs (ABK), especially children with emotional and behavioral disorders, the factors that cause emotional disorders and behavior with children with special needs, approaches that can be taken in overcoming the causes of emotional and behavioral disorders, and educational service models for children with special needs. who have emotional and behavioral disorders. This research is motivated by various cases that occur in relation to the limited education obtained by children with special needs, and even some of these children experience discriminatory treatment or are differentiated from ordinary children. This research method is descriptive with data collection techniques in the form of literature studies from various references relevant to the observed symptoms. The data collected were analyzed descriptively qualitatively so that it could be seen the variations in the characteristics and models of educational services for children with special needs with emotional and behavioral disorders. The results showed that children with emotional and behavioral disorders have characteristics including: intelligence and learning achievement, social and emotional characteristics and immature, withdrawal behavior. The education service model for children with special needs with emotional and behavioral disorders can be grouped into three groups, namely segregation education services, integrated / integrated education services, and inclusive education.
\end{abstract}

Keywords: Education Inclucive, Children with Special Needs, Emotional and Behavioral Disorders

\begin{abstract}
Abstrak
Penelitian ini bertujuan untuk menganalisis karakteristik anak berkebutuhan khusus (ABK) terutama anak dengan gangguan emosi dan perilaku, faktor-faktor yang menjadi penyebab gangguan emosi dan perilaku $A B K$, pendekatan yang bisa dilakukan dalam mengatasi penyebab gangguan emosi dan perilaku, serta model layanan pendidikan bagi ABK yang memiliki gangguan emosi dan perilaku. Penelitian ini dilatarbelakangi oleh adanya berbagai kasus yang terjadi berkaitan dengan keterbatasan pendidikan yang diperoleh anak berkebutuhan khusus, bahkan tidak sedikit anak tersebut mengalami perlakuan diskriminatif atau dibeda-bedakan dengan anak pada umumnya. Metode penelitian ini bersifat deskriptif dengan teknik pengumpulan data berupa studi literatur dari berbagai referensi yang relevan dengan gejala yang diamati. Data yang terkumpul dianalisis secara deskriptif kualitatif sehingga dapat dilihat variasi karakteristik dan model layanan pendidikan bagi anak berkebutuhan khusus dengan gangguan emosional dan perilaku. Hasil penelitian menunjukkan bahwa anak dengan gangguan emosi dan perilaku memiliki karakteristik meliputi inteligensi (kecerdasan) dan prestasi belajar, karakteristik sosial dan emosi seperti immature (belum dewasa) serta withdrawl behavior (menghindari kontak sosial). Model layanan pendidikan bagi anak berkebutuhan khusus (ABK) termasuk dengan anak yang mengalami gangguan emosi dan perilaku dapat dikelompokkan menjadi tiga yaitu layanan pendidikan segregrasi, layanan pendidikan terpadu/integrasi, dan pendidikan inklusi.
\end{abstract}

Kata Kunci: Pendidikan Inklusif, Anak Berkebutuhan Khusus, Gangguan Emosi dan Perilaku 


\section{Pendahuluan}

Makna pendidikan menurut Dr.H.Amka.M,si (2019) adalah suatu usaha manusia untuk membina kepribadiannya sesuai dengan nilai-nilai yang ada di dalam masyarakat dan kebudayaannya. Dengan demikian, bagaimanapun sederhananya peradaban suatu masyarakat, di dalamnya terjadi atau berlangsung suatu proses pendidikan. Oleh karena itu, pendidikan tidak mengenal batasan, pendidikan berlangsung sepanjang hayat dan bisa dilakukan dimana saja dan kapan saja oleh manusia serta mampu melakukan proses kependidikan (life long education) (Arriani, 2017; Fridayanthie, 2016a; Murniarti \& Anastasia, 2016; Rahayu, 2015).

Semua warga negara berhak mendapatkan pendidikan yang baik dan layak termasuk anak berkebutuhan khusus (ABK). Sebagaimana yang dijelaskan dalam Undang-undang Nomor 20 tahun 2003 tentang Sistem Pendidikan Nasional pasal 5 ayat (2) yang berbunyi "Warga Negara yang memiliki kelainan fisik, emosional, mental, intelektual, dan/atau sosial berhak memperoleh pendidikan khusus". Fasilitas pendidikan bagi anak berkebutuhan khusus telah disediakan oleh pemerintah yaitu dengan adanya lembaga pelayanan pendidikan bagi anak berkebutuhan khusus (ABK) atau pendidikan inklusif disekolah-sekolah. Anak berkebutuhan khusus memiliki berbagai jenis gangguan, salah satunya yaitu anak dengan gangguan emosi dan perilaku (Emotional and Behavioral Disorders).

Anak berkebutuhan khusus (ABK) dengan gangguan emosi dan perilaku memiliki karakteristik yang sama dengan perilaku anak-anak pada umumnya, seperti perilaku tidak penurut, berkelahi, perusakkan, mengucapkan kata-kata kotor dan tidak senonoh, suka memerintah, berperilaku tidak sopan, serta penyendiri. Karakteristik ini menyebabkan anak dengan gangguan emosi dan perilaku sulit untuk dideteksi karna karakteristik yang hampir sama dengan anak pada umumnya sehingga seringkali terjadi kesalahan dalam pemberian layanan pendidikan seperti dalam memperlakukan nya disamakan dengan anak pada umumnya (Indonesia \& Barat, 2019; Persada \& Efendi, 2018; Wati, 2014).

Anak berkebutuhan khusus (ABK) sering kali mendapat perlakuan diskriminatif atau dibeda-bedakan dengan yang lain, termasuk anak dalam gangguan emosi dan perilaku. Selain mendapat perlakukan diskriminatif, anak dalam gangguan emosi dan perilaku bahkan sulit untuk menerima pendidikan. Beberapa sekolah regular tidak mau menerima mereka sebagai siswa dikarenakan guru di sekolah tersebut tidak memiliki dasar pendidikan yang memadai untuk mengajar anak berkebutuhan khusus. Hal yang menjadi sulit nya mendapatkan pendidikan bagi anak berkebutuhan khusus adalah letak sekolah khusus yang jauh dari rumah mereka, sehingga banyak anak berkebutuhan khusus yang tidak mengenyam pendidikan yang layak mereka dapatkan.

Berdasarkan permasalahan yang dialami anak berkebutuhan khusus terutama anak dalam gangguan emosi dan perilaku, perlu adanya bantuan dari pemerintah dalam menyediakan fasilitas layanan pendidikan bagi anak berkebutuhan khusus dengan gangguan emosi dan perilaku di semua jenis jenjang pendidikan baik pedidikan dasar sampai pendidikan tinggi dalam sistem pembelajaran, fasilitas yang mendukung, serta peran guru yang sangat penting untuk memberikan motivasi dan arahan yang bersifat membangun kepada anak dalam gangguan emosi dan perilaku (Dermawan, 2018; Wathoni, 2013). Hal ini sesuai dengan Peraturan Pemerintah Nomor 17 tahun 2010 tentang Pengelolaan Penyelenggaraan Pendidikan pasal 133 yang berbunyi bahwa pemerintah memberikan kesempatan bagi anak berkebutuhan khusus, salah satunya dengan anak dengan gangguan emosi dan perilaku untuk dapat memperoleh layanan pendidikan yang sama dengan siswa reguler. Adapun fokus permasalahan yang akan dikaji dalam hal ini adalah pengertianya, karakteristik, faktorfaktor penyebab gangguan, pendekatan yang bisa dilakukan untuk menangani dan model layanan pendidikan yang digunakan untuk membantu anak berkebutuhan khusus terutama dengan gangguan emosi dan perilaku dalam belajar dan mengembangkan kreativitasnya.

\section{Metode}

Penelitian ini dilaksanakan bersifat deskriptif yaitu dengan teknik pengumpulan data berupa studi literatur dari berbagai referensi yang relevan dengan gejala yang diamati yaitu pada subjek anak berkebutuhan khusus (ABK) terutama dengan gangguan emosional dan 
perilaku (Emotional And Behavioral Disorder). Data yang terkumpul dianalisis secara deskriptif kualitatif sehingga dapat dilihat variasi karakteristik dan model layanan pendidikan bagi anak berkebutuhan khusus dengan gangguan emosional dan perilaku. Sehingga dengan mengetahui karakteristik dan variasinya maka dapat dilakukan pelayanan pendidikan yang tepat pada setiap gejala yang dialami.

\section{Hasil dan Pembahasan}

\section{Pengertian Gangguan Emosi dan Perilaku}

Di Indonesia, gangguan emosional dan perilaku (Emotional And Behavioral Disorder) sering dikenal dengan istilah Tunalaras. Gangguan emosional dan perilaku yaitu suatu keadaan dimana kondisi perilaku dan emosional seorang individu di sekolah/di luar sekolah sangat berbeda dari anak lainnya yang umumnya sesuai dengan anak seusianya, etnis, atau budaya. Gangguan emosi dan perilaku juga merupakan suatu individu yang mengalami kesulitan dalam penyesuaian diri dan bertingkah laku tidak sesuai dengan norma-norma yang berlaku dalam lingkungan kelompok usia, masyarakat, maupun keluarga sehingga dapat merugikan dirinya sendiri maupun orang lain, oleh karena itu memerlukan pelayanan pendidikan khusus dalam menangani dirinya maupun lingkungannya

Gangguan emosi dan perilaku dibagi menjadi dua jenis, yaitu externalizing behavior (Gangguan dari luar) dan internalizing behavior (Gangguan dari dalam). Externalizing behavior memiliki dampak langsung atau tidak langsung terhadap orang lain, contohnya perilaku agresif, membangkang, tidak patuh, berbohong, mencuri, dan kurangnya kendali diri. Internalizing behavior mempengaruhi anak dengan berbagai macam gangguan seperti kecemasan, depresi, penyendiri, mengalami gangguan makan, dan kecenderungan untuk bunuh diri. Kedua jenis tersebut memiliki pengaruh yang sama buruknya terhadap kegagalan dalam proses belajar di sekolah (Hallahan \& Kauffman,1988; Eggen \& Kauchak,1997).

\section{Karakteristik Anak dengan Gangguan Emosi dan Perilaku}

Karakteristik Anak dengan Gangguan Emosi dan Perilaku Heward \& Orlansky (1988) dalam Sunardi (1996) mengatakan bahwa seseorang yang mengalami gangguan perilaku apabila memiliki satu atau lebih dari lima karakteristik dalam kurun waktu yang lama. Karakteristik tersebut yaitu ketidakmampuan untuk belajar yang bukan disebabkan oleh faktor intelektualitas atau alat indra maupun kesehatan, ketidakmampuan untuk berbaur dengan teman sebaya dan pendidik, perasaan yang di bawah keadaan normal, seperti mudah terbawa suasana hati (emosi,labil), ketidakbahagiaan, depresi atau ketakutan-ketakutan akan permasalahan-permasalahan pribadi atau sekolah.

Dalam masalah pendidikan, beberapa anak dengan gangguan emosional dan tingkah laku berada pada kategori lambat dalam belajar (slow learner) dan ketidakmampuan intelektual ringan (mild intellectual disability). Sebagian besar anak yang memiliki gangguan emosional dan tingkah laku merupakan anak yang kurang berprestasi disekolahnya. Memiliki karakteristik dalam masalah sosial dan emosi seperti agresif, acting-out behavior (externalizing) Conduct disorder (gangguan perilaku). Perilaku-perilaku tersebut seperti memukul, berkelahi, mengejek, berteriak, pembangkang, merusak, vandalisme, bahkan memeras. Anak normal lain mungkin juga melakukan perilaku-perilaku tersebut namun masih mimikirkan akibat dari tindakan yang dilakukan., berbeda dengan anak dalam gangguan emosi dan perilaku. Mereka biasanya memiliki sikap yang melakukan tindakan tanpa memikirkan akibat dari apa yang dilakukan tersebut.

Karakterisktik lainnya yaitu Immature, withdrawl behavior (internalizing) anak dengan gangguan ini menunjukkan perilaku immature (tidak matang atau kekanak-kanakan) dan menarik diri dari orang lain. Anak dengan gangguan emosi dan perilaku biasanya mengalami keterasingan dari lingkungannya, kemungkinan hanya mempunyai beberapa orang teman saja sehingga dapat memungkinkan anak tersebut jarang bermain dengan anak seusianya serta kurang memiliki keterampilan sosial dan komunikasi untuk berbaur dengan yang lainnya. Beberapa diantara mereka mengasingkan diri untuk berkhayal, merasakan ketakutan yang tidak wajar, mengeluhkan permasalahan-permasalahan pribadi atau sekolah 
yang sedang dihadapi oleh anak ABK termasuk anak dalam gangguan emosi dan perilaku.

Secara umum karakteristik sosial dan emosional anak dengan gangguan emosional dan tingkah laku dapat dikatakan dengan tingkah laku yang tidak terarah seperti tidak menurut atau membangkang, perusakan, pengucapan kata-kata kotor dan tidak senonoh, suka memerintah, berperilaku kurang sopan, gangguan kepribadian (merasa rendah diri, cemas, pemalas, depresi, kesedihan yang mendalam, menarik diri dari pergaulan), tidak matang atau tidak dewasa dalam sikap, serta pelanggaran sosial seperti terlibat dalam perkelahian, mencuri bahkan membolos.

\section{Faktor-faktor Penyebab Gangguan Emosi dan Perilaku}

Beberapa faktor yang menyebabkan terjadinya gangguan emosi dan perilaku yaitu yang pertama faktor biologi, faktor lingkungan atau keluarga, faktor sekolah, dan faktor masyarakat (Rohmawati, 2017). Beberapa faktor biologi yang berhubungan dengan gangguan emosi dan perilaku tertentu, seperti anak-anak yang lahir dengan sindrom alkohol janin (kebiasaan ibu mengonsumsi minuman beralkohol) yang menunjukkan masalah dalam pengendalian impuls dan hubungan interpersonal yang dihasilkan dari kerusakan otak, malnutrisi (kekurangan nutrisi) dapat juga dapat menyebabkan perubahan perilaku, penalaran dan berpikir serta kelainan seperti skizofrenia (gangguan mental yang terjadi dalam jangka panjang) pada anak yang mungkin memiliki dasar genetik.

Yang kedua yaitu faktor keluarga, keluarga berperan penting dalam perkembangan anak-anak dalam segi kepribadian, perasaan dan sikap sosial. Namun, terdapat beberapa aspek yang dilakukan oleh sebagian keluarga yang dapat membuat anak mengalami gangguan emosi dan perilaku. Aspek-aspek tersebut yaitu penerapan pola asuh yang tidak konsisten, tidak adanya penerapan disiplin pada anak, Penolakan dan pengabaian dari orangtua, adanya orangtua atau orang dewasa yang menjadi model negatif bagi anak, kualitas rumah tangga seperti broken home atau sering terjadi perkengkaran pada orangtua, kematian salah satu orangtua yang memicu stres pada single parent, status ekonomi keluarga, perlakuan orangtua yang tidak adil, tuntutan dari orang tua, dan hukuman fisik yang berlebihan.

Yang ketiga yaitu faktor sekolah. Lingkungan sekolah merupakan tempat berkembangnya penyimpangan tingkah laku anak. Namun, lingkungan sekolah juga dapat menyebabkan adanya gangguan emosi dan perilaka terhadap anak. Beberapa sikap pihak sekolah yang dapat berpengaruh pada gangguan emosi dan perilaku anak antara lain disiplin dan tata tertib yang terlalu kaku, inkonsistensi pelaksanaan disiplin dan tata tertib, anak dituntut untuk harus berprestasi disekolah, kepribadian guru yang negatif, perlakuan guru yang tidak adil terhadap siswa, dan kemampuan manajemen waktu guru yang rendah.

Yang terakhir yaitu faktor masyarakat. Masyarakat juga dapat berperan dan berpengaruh dalam membentuk kepribadian dan perilaku anak. Namun, faktor masyarakat juga dapat menyebabkan gangguan emosi dan perilaku pada anak. Faktor tersebut seperti kemiskinan ekstrim disertai dengan gizi buruk pada lingkup masyarakat, keluarga yang tidak berfungsi, serta lingkungan yang penuh kekerasan seperti perampokan dapat mengakibatkan atau memperburuk gangguan emosi atau perilaku pada anak.

\section{Pendekatan dalam Usaha Mengatasi Anak dengan Gangguan Emosi dan Perilaku}

Pendekatan dalam dunia pendidikan adalah cara untuk memulai suatu pembelajaran atau suara proses belajar-mengajar yang dilakukan antara murid dan guru. Ada beberapa pendekatan yang dapat dilakukan dalam usaha mengatasi permasalah anak dengan gangguan emosi dan perilaku. Pendekatan tersebut yaitu pendekatan biomedis, pendekatan psikodinamik, pendekatan Pendidikan, dan pendekatan ekologi.

Pendekatan yang pertama yaitu pendekatan biomedis, pendekatan ini berhubungan dengan ilmu medis. Dimana berusaha memandang dan memperlakukan anak dengan gangguan emosi dan perilaku dari sudut pandang ilmu kedokteran baik pada pemberian obat atau penanganan secara medis. Selain itu, orangtua dan guru juga dapat berkerja sama dengan ahli medis, dokter atau psikiater dalam melakukan treatment pengobatan kepada anak sehingga anak mendapatkan penanganan medis. Pendekatan ini cenderung dilakukan 
pada anak ketunalarasan karena cedera neurologis.

Pendekatan yang kedua yaitu psikodinamik. Pendekatan psikodinamik menekankan pada segi psikologis anak untuk mengatasi adanya kelainan mendasar pasa perilaku, perasaan dan emosi anak. Strategi dalam pendekatan ini yaitu memahami dan memecahkan masalah yang menitikberatkan pada penyebab-penyebab hambatan yang dialami anak. Pendekatan ini biasanya dilakukan oleh konselor, psikolog, psikiater, dan atau pekerja sosial, bahkan guru.

Pendekatan yang ketiga yaitu pendekatan pendidikan. Peran orangtua dan guru sangat penting dalam pendekatan ini terutama pada anak dengan gangguan emosi dan perilaku. Biasanya anak dengan gangguan emosi dan perilaku kurang mampu dalam hal konsentrasi, oleh karena itu anak yang mengalami gangguan emosi dan perilaku kurang dapat mengikuti pembelajaran dengan baik. Strategi yang dapat dilakukan dalam mengatasi anak dengan gangguan emosi dan periaku yaitu program pengajaran harus tertata rapi, indikator dan tujuan pembelajaran yang, pembentukan suasana belajar yang baik, kondusif, dan ramah.

Pendekatan yang keempat yaitu pendekatan ekologi. Pendekatan ini berfokus pada konteks lingkungan, seperti masyarakat, teman, sekolah bahkan keluarga. Keempat peran tersebut sangat penting dalam mengatasi anak dengan gangguan emosi dan perilaku. Strategi yang dapat dilakukan yaitu lingkungan masyarakat, teman, sekolah dan keluarga harus saling mendukung dan merangkul anak dengan gangguan emosi dan perilaku, selain itu lingkungan tersebut juga harus menerima serta menganggap anak tersebut sama dengan mereka sehingga anak dengan gangguan emosi dan perilaku akan merasa nyaman.

\section{Model Layanan Pendidikan Bagi Anak Berkebututuhan Khusus dengan Gangguan Emosi dan Perilaku}

Dalam memilih model layanan pendidikan yang sinkron maka identifikasi sangat penting dilakukan oleh seorang pengajar untuk mengenali keberadaan anak dengan gangguan emosi dan perilaku. Identifikasi juga menjadi kunci keberhasilan proses pendidikan anak. Pada program pendidikan, kegiatan identifikasi anak dengan kebutuhan khusus mempunyai lima fungsi yaitu penjaringan (screening), pengalihtanganan (referal), klasifikasi, perencanaan pembelajaran dan pemantaun kemajuan belajar. Langkah-langkah instrumen identifikasi ini berguna untuk menghimpun data kondisi semua peserta didik pada kelas berdasarkan gejala yang nampak pada peserta didik, menganalisis data serta mengklasifikasi anak buat menemukan anak yg tergolong anak dengan gangguan emosi dan perilaku serta mencatat temuan sesuai gejala emosi serta perilaku, kemudian memisahkannya dengan siswa biasa.

Penjaringan (screening) yaitu menandai tanda-tanda anak dengan gangguan emosi serta perilaku pada lingkungan kelas atau sekolah menggunakan indera identifikasi yang sudah ditetapkan, sehingga akan dapat dibedakan antara anak dengan gangguan emosi dan sikap dengan peserta didik-siswa normal atau berkebutuhan khusus lain.

Pengalihtanganan (referal) yaitu menetapkan apakah anak cukup ditangani oleh pengajar di sekolah saja atau perlu melibatkan pihak atau pakar yang memiliki kemampuan khusus untuk menangani anak dalam gangguan emosi dan perilaku. Perilaku dan emosi siswa dilihat terlebih dahulu, jika masih bisa dikendalikan oleh pengajar maka tidak perlu melibatkan pihak atau pakar begitu juga sebaliknya.

Klasifikasi yaitu kegiatan memilah-milah mana anak dengan gangguan emosi dan sikap yang memerlukan penanganan lebih lanjut dan mana yg pribadi bisa mengikuti pelayanan pendidikan khusus pada kelas regular (Awwad, 2015; dermawan, 2018; Rahayu, 2015). Klasifikasi bisa dilihat dari tingkah laku anak yang memiliki gangguan emosi dan perilaku seperti perilaku yang tidak terarah, sering terlibat perkelahian, perusakan, pengucapan kata-kata kotor dan tidak senonoh, senang memerintah, berperilaku kurang sopan, gangguan kepribadian seperti merasa rendah diri, cemas, pemalas, depresi, kesedihan yang mendalam, menarik diri dari pergaulan, tidak dewasa dalam sikap dan sulit berkonsentrasi. 
Perencanaan pembelajaran yaitu penyusunan atau perencanaan sistem pembelajaran yang diindividualisasikan sinkron digunakan pada setiap jenis serta tingkat anak dengan gangguan emosi dan perilaku hasil penjabaran. Perencanaan pembelajaran harus mempertimbangkan situasi, kondisi nyata serta potensi yang ada di sekolah masingmasing untuk diikembangkan oleh setiap guru. Pemantauan kemajuan belajar, buat mengetahui keberhasilan program pembelajaran dalam kurun waktu saat eksklusif, dan peninjauan atas kegagalan acara dan beberapa aspek yg berkaitan, seperti diagnosis yg tidak tepat, atau pelaksanaan acara yang perlu diperbaiki (Agustin, 2017; Arriani, 2017; Persada \& Efendi, 2018).

Setelah melakukan proses identifikasi maka guru/pengajar dapat menentukan model layanan pendidikan bagi anak berkebutuhan khusus dengan gangguan emosional dan perilaku. Berikut ini merupakan tiga bentuk layanan pendidikan untuk anak dengan gangguan emosional dan perilaku :

\section{Layanan Pendidikan Segregrasi}

Sistem layanan pendidikan segregasi adalah sistem pendidikan yang terpisah dari sistem pendidikan anak normal. Pendidikan anak berkebutuhan khusus melalui sistem segregasi adalah penyelenggaraan pendidikan yang dilaksanakan secara khusus, dan terpisah dari penyelenggaraan pendidikan untuk anak normal. Penyelenggaraan pendidikan dengan sistem segregasi terbagi menjadi tiga yaitu sekolah luar biasa untuk tunalaras (slbe), berasrama kelas jauh/kelas kunjung, dan sekolah dasar luar biasa (sdlb) (Agustin, 2017; Arriani, 2017; Fridayanthie, 2016a; Indonesia \& Barat, 2019; Nugroho \& Mareza, 2016; Persada \& Efendi, 2018; Wathoni, 2013).

Sekolah Luar Biasa Berasrama (SLB-E untuk tunalaras) merupakan bentuk sekolah luar biasa yang didalam nya dilengkapi dengan fasilitas asrama sehingga anak dengan gangguan emosi dan perilaku dapat tinggal diasrama tersebut. SLB berasrama merupakan pilihan sekolah yang sesuai bagi anak dengan gangguan emosi dan perilaku yang berasal dari luar daerah karena terhalang oleh jarak atau fasilitas transportasi yang kurang memadaidan juga bagi anak dengan gangguan emosi dan perilaku yang sengaja diterlantarkan oleh keluarga mereka.

Kelas jauh adalah lembaga yang disediakan untuk memberi pelayanan pendidikan bagi anak berkebutuhan khusus yang tinggal jauh dari SLB. Penyelenggaraan kelas jauh ditujukan untuk menuntaskan wajib belajar serta pemerataan kesempatan belajar. Sekolahsekolah yang khusus mendidik anak dengan gangguan emosi dan perilaku masih sangat terbatas di kota/kabupaten. Oleh karena itu, dengan adanya kelas jauh ini diharapkan layanan pendidikan bagi anak dengan gangguan emosi dan perilaku semakin luas. Dalam penyelenggaraan kelas jauh menjadi tanggung jawab SLB terdekatnya. Tenaga guru yang bertugas di kelas tersebut berasal dari guru SLB-SLB yang ada didekat nya.

Sekolah Luar Biasa dengan Guru kunjung adalah salah satu pelayanan pedidikan untuk anak berkebutuhan khusus termasuk anak dengan gangguan emosi dan perilaku. Berbeda dengan kelas jauh, kelas kunjung ini merujuk pada ABK yang tidak siap untuk mengikuti proses pembelajaran. Oleh karena itu, guru berfungsi sebagai guru kunjung (itenerant teacher) untuk datang kerumah-rumah ABK untuk memberikan pelajaran. Sistem layanan ini memiliki kelebihan dan kelemahan nya. Kelebihan nya yaitu anak dapat belajar layak nya anak pada umumnya, anak akan menjadi termotivasi dan dapat bersaing secara sehat dengan sesama anak lainnya. Adapun kelemahan dari sistem ini yaitu anak menjadi terpisah dari lingkungan anak lainnya sehingga dapat menyebabkan anak akan sulit bergaul dengan anak yang lain, anak akan merasa dibatasi dalam hal pergaulan karna hanya bergaul dengan anak-anak berkebutuhan khusus lainnya, serta anak akan merasa ketidakadilan dalam kehidupan bersekolah bagi mereka yang termasuk berkebutuhan khusus. 


\section{Layanan Pendidikan Integrasi atau Terpadu}

Sistem pendidikan integrasi disebut juga sistem pendidikan terpadu. Layanan pendidikan integrasi atau terpadu adalah bentuk layanan pendidikan yang memberikan kesempatan kepada anak berkebutuhan khusus termasuk anak dalam gangguan emosi dan perilaku untuk belajar bersama-sama dengan anak biasa pada umumnya (normal) di sekolah umum (Khusus et al., 2015; Noviandari \& Huda, 2018; Nuraini, 2013). Dengan kata lain, sistem pendidikan ini yang membawa anak dengan gangguan emosi dan perilaku kepada suasana keterpaduan dengan anak normal. Keterpaduan tersebut dapat bersifat menyeluruh, sebagaian, atau keterpaduan dalam rangka sosialisasi.

Pada sistem keterpaduan secara penuh dan sebagian, terdapat jumlah batasan tertentu anak berkebutuhan khusus termasuk dengan gangguan emosi dan perilaku dalam satu kelas. Di sekolah terpadu disediakan Guru Pembimbing Khusus (GPK) untuk membantu anak dengan gangguan emosi dan perilaku. Selain itu, GPK juga berfungsi sebagai konsultan bagi para pengajar seperti guru kelas, kepala sekolah, atau anak dengan gangguan emosi dan perilaku itu sendiri, sebagai pembimbing di ruang bimbingan khusus atau guru kelas pada kelas khusus. Terdapat tiga bentuk keterpaduan dalam layanan pendidikan bagi anak berkebutuhan khusus dengan gangguan emosi dan perilaku menurut Dekdiknas (1986) yaitu bentuk kelas biasa, kelas biasa dengan ruang bimbingan khusus dan bentuk kelas khusus.

Pertama, bentuk kelas biasa. Dalam bentuk ini, anak berkebutuhan khusus termasuk anak dengan gangguan emosi dan perilaku belajar di kelas biasa secara penuh menggunakan kurikulum yang sama dengan kurikulum sekolah tersebut berlaku. Bentuk keterpaduan ini sering juga disebut keterpaduan penuh. Dalam keterpaduan ini guru pembimbing khusus hanya berfungsi sebagai konsultan bagi kepala sekolah, guru kelas/guru bidang studi, atau orangtua anak berkebutuhan khusus. Sebagai konsultan bagi pihak sekolah, guru pembimbing khusus berfungsi untuk penasehat mengenai kurikulum, maupun permasalahan dalam proses belajar-mengajar bagi anak berkebutuhan khusus. Oleh karena itu, perlu adanya ruang konsultasi untuk guru pembimbing khusus, pendekatan, metode dan cara penilaian yang digunakan pada kelas biasa ini sama dengan yang digunakan pada sekolah reguler.

Kedua, kelas biasa dengan ruang bimbingan khusus. Bentuk keterpaduan ini sering disebut juga dengan keterpaduan sebagian. Dalam bentuk yang kedua ini, anak berkebutuhan khusus dengan gangguan emosi dan perilaku belajar di kelas biasa menggunakan kurikulum biasa serta mengikuti pelayanan khusus untuk mata pelajaran tertentu yang tidak dapat diikuti bersama dengan anak normal. Jadi, anak dengan gangguan emosi dan perilaku ini bersekolah bersama dengan anak pada umum nya namun ada pelajaran khusus untuk mereka yang dibimbing khusus oleh guru pembimbing khusus (GPK) melalui pendekatan individu dan metode peragaan yang sesuai.

Ketiga, bentuk kelas khusus. Bentuk keterpaduan ini disebut juga keterpaduan lokal bangunan atau keterpaduan yang bersifat sosialisasi. Dalam bentuk kelas khusus, anak berkebutuhan khusus (ABK) termasuk anak dengan gangguan emosi dan perilaku mengikuti pendidikan sama dengan kurikulum di SLB secara penuh di kelas khusus pada sekolah umum yang melaksanakan program pendidikan terpadu. Guru Pembimbing khusus berfungsi sebagai pelaksana program dikelas khusus tersebut.

Pendekatan, metode, dan cara penilaian dalam bentuk kelas khusus ini sama dengan pendekatan, metode, dan cara yang digunakan di SLB. Keterpaduan pada tingkat ini hanya bersifat fisik dan sosial, yang berarti anak berkebutuhan khusus hanya dipadukan dalam kegiatan yang bersifat non akademik, seperti olahraga, keterampilan, atau sosialisasi pada waktu jam-jam istirahat atau acara tertentu. 
Kesepakatan Internasional Convention on the Rights of Person with Disabilities and Optional Protocol yang disahkan pada Maret 2007 mendorong terwujudnya sistem pendidikan inklusif. Pada pasal 24 dalam Konvensi ini disebutkan bahwa setiap negara berkewajiban untuk menyelenggarakan sistem pendidikan inklusi di setiap tingkatan pendidikan. Tujuan dari terlaksananya pendidikan inklusif ini adalah untuk mendorong terwujudnya partisipasi penuh anak berkebutuhan khusus dalam kehidupan masyarakat dan memberikan kesempatan seluas-luasnya kepada semua anak mendapatkan pendidikan yang layak sesuai dengan kebutuhannya, membantu mempercepat program penuntasan wajib belajar pendidikan dasar dan menengah dengan menekan angka tinggal kelas dan putus sekolah, selanjutnya yaitu menciptakan sistem pendidikan yang menghargai keberagaman, tidak diskriminatif, serta ramah terhadap pembelajaran.

Pendidikan inklusif memungkinkan siswa untuk belajar bersama dengan anak normal lainnya disatu sekolah reguler dan menyatakan penerimaan sepenuhnya pada anak berkebutuhan khusus, termasuk didalamnya anak-anak dengan ganggaun emosi dan perilaku. Beberapa hal yang sebenarnya menyebabkan pendidikan inklusif banyak direkomendasikan untuk pendidikan berkebutuhan khusus dengan gangguan emosi dan perilaku yaitu pendidikan inklusif tidak memandang semua jenis siswa berbeda namun menganggapkan sama. Dalam pendidikan inklusif, mereka menghindarkan semua aspek negatif seperti labeling dan pendidikan inklusif sendiri selalu melakukan checks dan balances. Pendidikan ini menyatakan bahwa anak yang beresiko tidak disukai bahkan mengalami penolakan lingkungan (Farell, 2008) sebagai sesuatu yang khas menimpa anak berkebutuhan khsus dengan gangguan emosi dan perilaku.

Labeling merupakan hal yang dapat memberikan dampak buruk pada mereka yang diberi label negatif terutama anak-anak berkebutuhan khusus (Agustin, 2017; Fridayanthie, 2016b; Praptiningrum, 2012; Wathoni, 2013). Secara nyata, pendidikan inklusif tersebut berusaha menghindari label negatif dengan mengubah label yang ada dimasa lalu menjadi lebih positif dimasa sekarang ini. Dalam konteks pendidikan anak berkebutuhan khusus temasuk anak dengan gangguan emosi dan perilaku, checks dan balances sangat penting. Pihak sekolah saling berkerja sama berperan sebagai penyedia layanan yang baik, orangtua siswa sebagai guru sekaligus mendiagnosis (diagnostician) gangguan emosi dan perilaku anak di rumah, komite sekolah yang berperan dalam advokasi atas berbagai resiko gangguan emosi dan perilaku yang ditimbulkan anak, dan ahli psikiatri serta psikolog sebagai penentu dan pemberi penanganan klinis gangguan emosi dan perilaku.

Hal yang juga penting untuk pendidikan anak dengan gangguan emosi dan perilaku adalah sekolah ramah (welcoming school). Sekolah ramah (welcoming speech) terdapat dari beberapa komunitas dalam sekolah, seperti guru dan anak-anak yang bekerja sama untuk meminimalkan hambatan yang dihadapi anak dalam belajar dan mempromosikan keikutsertaan dari seluruh anak di sekolah. Tujuan pendidikan sama untuk semua anak yaitu berhak mempunyai hak untuk merasa aman dan nyaman, untuk mengembangkan diri, untuk membuat pilihan, untuk berkomunikasi dan bersosialisasi, untuk mampu hidup dalam situasi dunia yang terus menerus berubah, untuk menghadapi banyak rintangan atau cobaan dalam hidup, dan untuk memberi kontribusi yang bernilai.

Setiap model layanan pendidikan yang dikembangkan akan berhasil jika guru sebagai pengajar sekaligus pendamping siswa dapat mampu mengkondisikan supaya kebutuhan pendidikan bagi masing-masing anak terpenuhi dengan baik dan benar. Seorang guru atau pengajar harus melakukan hal yang mendasar terhadap anak berkebutuhan khusus yaitu menghilangkan persepsi negatif pada anak, guru harus senantiasa menyadari bahwa pengelolaan pembelajaran yang dilakukan adalah berbeda dengan pembelajaran pada umumnya, berefleksi dan memiliki harapan pada peserta didiknya, apabila peserta didik belum mampu mencapai tujuan pembelajaran maka guru juga harus melakukan refleksi terhadap metode dan startegi yang dirancang serta menaruh harapan tersendiri pada peserta didik agar kelak mereka mampu memiliki kemampuan untuk pencapaian hasil belajar yang lebih baik lagi, guru harus menjadi panutan yang positif bagi anak berkebutuhan khusus, jangan membentak peserta didik karna mereka cenderung mudah sedih, dan yang paling penting yaitu guru harus sabar dalam menghadapi anak berkebutuhan khusus. 


\section{Kesimpulan Dan Saran}

Berdasarkan hasil penelitian dapat disimpulkan beberapa hal. Pertama, anak berkebutuhan khusus terutama dengan gangguan emosi dan perilaku yaitu anak yang mengalami kesulitan dalam penyesuaian diri baik dari segi emosi dan perilaku, seperti bertingkah laku yang tidak sesuai dengan kelompok umurnya (suka memerintah, berkata kasar, perkelahian dII). Kedua, karakteristik anak dengan gangguan perilaku dan emosi yaitu inteligensi dan prestasi belajar, karakteristik sosial dan emosi. agresif, acting-out behavior (externalizing), dan kurang dewasa (immature) serta withdrawl behavior (internalizing). Ketiga, beberapa faktor yang menyebabkan terjadinya gangguang emosi dan perilaku yaitu faktor biologis, faktor lingkungan, faktor keluarga, faktor sekolah, dan faktor masyarakat. Keempat, beberapa pendekatan yang dapat dilakukan dalam usaha mengatasi permasalahan anak dengan gangguan emosi dan perilaku yaitu pendekatan biomedis, pendekatan psikodinamik, pendekatan perilaku, pendekatan pendidikan, dan pendekatan ekologi. Kelima, model layanan pendidikan bagi anak berkebutuhan khusus dapat dikelompokkan menjadi tiga model yaitu bentuk layanan pendidikan segregrasi; bentuk layanan pendidikan terpadu/integrasi, dan pendidikan inklusif.

Berdasarkan simpulan tersebut dapat dikemukakan saran yaitu model layanan pendidikan yang dirancang harus mampu memfasilitasi berbagai kebutuhan yang melekat pada anak berkebutuhan khusus dengan gangguan emosi dan perilaku. Guru, fasilitas penunjang kreativitas anak, kurikulum, lingkungan belajar berperan penting dalam memotivasi anak untuk meningkatkan motivasi dan hasil belajar. Guru maupun orang tua harus bisa mengenali karakteristik masing-masing anak, karena karakteristik anak yang berbeda-beda juga memerlukan metode dan pendekatan yang digunakan dalam proses pendampingan kegiatan pembelajaran juga berbeda-beda untuk mencapai tujuan pembelajaran dengan baik. 


\section{Daftar Pustaka}

Amka, (2019), Buku Ajar Filsafat Pendidikan, Gagasan Konsep, Teori dan Analisis Filosofis Mengenai Sistem Pendidikan. Nizamia Learning Center, Sidoarjo.

Karang Widiastuti,N. (2020). Layanan Pendidikan Anak Berkebutuhan Khusus Dengan Gangguan Emosi Dan Perilaku, 3(2).

Arriani, F. (2017). Kebijakan Layanan Pendidikan Untuk Anak Berkebutuhan Khusus (Abk) Di Satuan Pendidikan Anak Usia Dini (Paud). AWLADY: Jurnal Pendidikan Anak, 3(1), 118. Https://Doi.Org/10.24235/Awlady.V3i1.1217

Persada, H. J., \& Efendi, M. (2018). Studi Kasus Implementasi Layanan Pendidikan Inklusif Di Kota Madiun. Jurnal Ortopedagogia, 4(1), 7-11. Https://Doi.Org/10.17977

Dermawan, O. (2018). Strategi Pembelajaran Bagi Anak Berkebutuhan Khusus Di Slb. Psympathic: Jurnal Ilmiah Psikologi, 6(2), 886-897. Https://Doi.Org/10.15575/ Psy.V6i2.2206

Hallahan, D.P. \& Kauffman, J.M. (1988). Exceptional Children: Introduction To Special Education. $4^{\text {th }}$ Ed. New Jersey: Prentice Hall.

Rohmawati, Ulva Badi. 2017. Peran Keluarga Dalam Mengurangi Gangguan Emosional Pada Anak Berkebutuhan Khusus. Jurnal Pendidikan Islam. Volume II Nomor 2

Awwad, M. (2015). Urgensi Layanan Bimbingan Dan Konseling Bagi Anak Berkebutuhan Khusus. Al-Tazkiah: Jurnal Bimbingan Dan Konseling Islam, 4(1), 46-64.

Anggriana, T. M., \& Trisnani, R. P. (2016). Kompetensi Guru Pendamping Siswa Abk Di Sekolah Dasar. Jurnal Konseling Gusjigang, 2(2), 157-164. Https://Doi.Org/10.24176 /Jkg.V2i2.702

Noviandari, H., \& Huda, T. . (2018). Peran Sekolah Dalam Pendidikan Anak Berkebutuhan Khusus Di Sdlb Pgri Bangorejo Banyuwangi. Jurnal Psikologi, 5(1), $29-37$.

Bower, Gordon, H. Ersnest. 1981, Theoriest Of Learning. Engle Wood Clift: Prentice Hall

Farrel, Michael (2008). Inclusion At The Crossroads, Special Education-Concept And Values.Usa: David Fulton Publisher.

Dermawan, O. (2018). Strategi Pembelajaran Bagi Anak Berkebutuhan Khusus Di Slb. Psympathic: Jurnal Ilmiah Psikologi, 6(2), 886-897. Https://Doi.Org/10.15575/ Psy.V6i2.2206

Fridayanthie, E. Wida. (2016a). Manfaat Program Pendidikan Inklusi Untuk Aud Nurul. Jurnal Pendidikan Anak, 3(1), 56. Https://Doi.Org/Https://Doi.Org/10.3929/Ethz-B-000238666

Fridayanthie, E. Wida. (2016b). Pengembangan Model Deteksi Dini Anak Berkebutuhan Khusus (Abk) Pada Tingkat Pendidikan Anak Usia Dini (Paud) Di Kota Malang. Jurnal IImiah Psikologi Terapan, 3(1), 56. Https://Doi.Org/Https://Doi.Org/10.3929/Ethz-B000238666

Hallahan, D.P. \& Kauffman, J.M. (2006). Exceptional Learners: Introduction To Special Education 10th Ed. USA: Pearson.

Indonesia, U. P., \& Barat, J. (2019). Model Manajemen Pendidikan Life Skill Pada Anak Berkebutuhan Khusus. Jurnal Penelitian Pendidikan, 18(3), 306-317.

Murniarti, E., \& Anastasia, N. Z. (2016). Pendidikan Inklusif Di Tingkat Sekolah Dasar: Konsep, Implementasi, Dan Strategi. Jurnal Dinamika Pendidikan, 9(1), 9-18.

Nugroho, A., \& Mareza, L. (2016). Model Dan Strategi Pembelajaran Anak Berkebutuhan Khusus Dalam Setting Pendidikan Inklusi. Jurnal Pendidikan Dasar Perkhasa, 2(2).

Nuraini. (2013). Peran Orang Tua Dalam Penerapan Pendidikan. Jurnal Kependidikan, 03(01), 63-86.

Um031v4i12018p007

Praptiningrum, N. (2012). Fenomena Penyelenggaraan Pendidikan Inklusif Bagi Anak Berkebutuhan Khusus. In Jpk: Jurnal Pendidikan Khusus (Vol. 7, Issue 2). Https://Doi.Org/10.21831/Jpk.V7i2.774

Rafikayati, Ana, \& Jauhari, M. N. (2018). Keterlibatan Orangtua Dalam Penanganan Anak Berkebutuhan Khusus. Jurnal Abadimas Adi Buana, 2(1), 55-64. Https:// Doi.Org/10.36456/Abadimas.V2.I1.A1636

Rahayu, S. M. (2015). Memenuhi Hak Anak Berkebutuhan Khusus Anak Usia Dini Melalui 
Pendidikan Inklusif. In Jurnal Pendidikan Anak (Vol. 2, Issue 2). Https://Doi.Org/10.21831/Jpa.V2i2.3048

Sunardi. (1996). Ortopedagogik Anak Tunalaras I, Depdiknas Dikti.

Tirtayani, Luh Ayu. 2017. Upaya Pendampingan Anak Berkebutuhan Khusus Pada Lembaga-Lembaga PAUD Di Singaraja, Bali. Proyeksi, Vol. 12(2). 